\title{
Honorific Communities: the Recipients of Gifts at Delphi
}

Since honorific culture includes both honours and their recipients, this chapter supplements Chapters 2 and 3 by considering the recipients of Delphic gifts. The two previous chapters have discussed trends and tendencies in granting privileges at Delphi and the range of the Delphic proxeny network. In this chapter, the focus is placed on the profession, social background and gender of those praised with honours at Delphi. The following key questions concern the evolution of the categories of honorands and the status of the recipients of Delphic gifts. How many honorands belonged to the royal circle and imperial family, and how many belonged to the upper echelons of their communities? How did Delphi position itself with regard to both the dominant Hellenistic monarchs, and, later, to Rome and its emperors? What were the gender dynamics of the honorands at Delphi? And how many of the overall honorands were collective as opposed to individual honorands?

By going beyond conventional discussions on the types of honorands granted gifts in Greece, I will once again turn to Mack's concept of the network to examine honorands who originated from remote and neighbouring territories. ${ }^{1}$ Mack identifies three types of regional interaction between poleis: (a) a narrow network; (b) a network with more distant regions; and (c) a wide network. ${ }^{2}$ Within the narrow network of Delphic honorands one should include

1 Constantakopoulou discusses dedicators at Delos by contrasting men and women, private individuals and collective donors, and Delians and non-Delians (2017, 19-227). She also divides dedicators originating from three zones: dedicants from the neighbouring area; those from the region beyond the neighbouring area but still within the Aegean basin; and those from the region beyond the Aegean basin (206-207). Domingo Gygax (2016) and Quass (1993) also use the chronological approach in revealing the categories of benefactors in Greece. Biard divides honorands in groups depending on their occupations (2017). Wilding explores Oropean proxenoi using regional interactions (2015). Gauthier focuses on honorands' origin and social status (1985). In the case of Delphi, van Liefferinge examines all people who performed there, including poets and musicians, actors, philosophers, teachers (grammarians), and astronomers (2000, 149-164). Bouvier (1985, 119-135) discusses 'men of letters' granted with honours at Delphi with a focus on their origin and the gifts conferred upon them. Bouchon (2013, 171-193) examines only musicians praised at Delphi, while Perrot (Perrot 2013, 195-210) pays attention to Delphic female artists.

2 Mack 2015. 
the inhabitants of central Greece, Attica and the Peloponnese. Macedonians and citizens from Epirus, the Aegean islands and the west coast of Asia Minor belong to the more distant network, while people from the Propontic area, the Hellespont, the Black Sea region, the south coast of Asia Minor, Syria, Cyprus, Egypt and Magna Graecia are interpreted as belonging to the wide network of honorands. ${ }^{3}$ This approach allows the types of honorands to be distinguished by taking the following factors into account: the place of origin, occupation and sex of the honorand, and the types of links which Delphi had with particular regions. This approach will reveal whether they were any particular connections between territories and certain types of honorands; how did the citizens of the peripheral areas earn Delphic privileges and how were they obtained by Delphi's neighbours? Were there any patterns in the regional distribution of honorands? These questions cannot be easily answered mostly due to the fact that the core of this chapter consists of a sample of a little over 950 epigraphically recorded honorands from Delphic decrees and tituli honorarii. Moreover, the sample has a wide geographical scope, covering regions from Massalia ${ }^{4}$ (the westernmost city attested as having proxenoi of Delphi) to Pantikapaion ${ }^{5}$ (the easternmost example). Chronologically, the material extends from the early fourth century BCE to the late fourth century CE.

To begin with, this chapter discusses only those documents which fulfill the following criteria: the decree or titulus honorarius has to reveal the gender of the honorand(s), his/her occupation, or, at least, the character of the grant (collective or individual). Origin is taken into account when assigning honorands to particular networks, but in contrast to the previous chapter it is not regarded as a decisive factor in this context.

Up to 866 Delphic honorific decrees and 96 tituli honorarii ${ }^{6}$ reveal the sex of the honorand(s) and the character of the grant (collective/individual). Regrettably, many of the recipients of Delphic gifts attested in abbreviated decrees are completely unknown to us, as they do not appear in any other kind of source, epigraphic or literary. Thus, the number of documents that provide information about the profession of the honorands is much lower than the ratio of texts that reveal, e.g., their gender. The roles of individuals praised at Delphi either (1) appears directly in the text of the inscription; (2) is known

3 Chapter 3 .

4 Syll $^{3} 5^{8} 5$.

5 Syll ${ }^{3} 585$.

$6 \quad 32$ private honorific inscriptions and 64 public. 
from other evidence; ${ }^{7}$ (3) can be deduced from the motivation clause; ${ }^{8}$ or, (4) on some occasions, can be identified through the decorations that appear on the stone upon which the inscription was engraved. ${ }^{9}$ However, it would be hasty to conclude that the 'function' performed by the honorand is always linked to the context for the award of honours. For example, it is not necessary that a doctor served the city with medical service, as he could have established links with Delphi by other means. ${ }^{10}$ This phenomenon will be discussed further in the next chapter. ${ }^{11}$ It is sufficient to say that, since the aim of this chapter is to study the social status and the background of the honorands, rather than the motivation behind the granting of privileges, the professions of honorands revealed by our sources help to pave the way for necessary studies.

In total, only $31 \%$ of preserved material reveals the occupation of the recipients of Delphic gifts, while the origin of $95 \%$ of these honorands can be attributed with certainty. The honorands whose ethnicity and profession can be established are divided into three categories depending on the type of network they represent. Surprisingly, the documents from the imperial period (over $40 \%$ of texts) provide more details regarding the profession of honorands than the Hellenistic texts (only $13 \%$ ). ${ }^{12}$ This uneven proportion should be linked to the pattern of abbreviated decrees dated to the third century вСЕ, which was the 'golden age' of the Delphic decree habit. The bulk of abbreviated decrees from this era contains little in the way of the set formulae that appear later. In other words, texts from imperial times reveal more information regarding honorands than the more numerous inscriptions from the Hellenistic period. Bouchon attributes this trend to the Delphic epigraphic fashion of the time; sometime around the first century $\mathrm{CE}$ it became habitual to inscribe the profession of the honorand in the text of inscription, especially in decrees

For instance, Nearchos, son of Androtimos from Crete, was a historian, but this information was not included in the text of the Delphic decree $(F d D$ 1.412); it is rather known from other evidence, see Chaniotis 1988 E37.

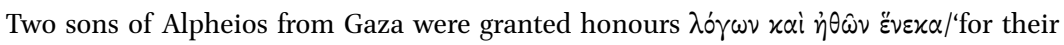
words and manners' which, according to Puech (2002, no. 55), indicates that they might have been rhetors and that they participated in a kind of rhetorical-oratorical contest at Delphi (FdD 2.109).

Decree for Nikodromos, son of Theodoros from Chalkis is adorned with a sketch of lyre which might suggest that Nikodromos was a musician ( $F d D$ 2.207), see Nachtergael 1977, no. 13 .

10 Marek 1984, 335-385. Pace Marek, Mack 2015, 59-65; Constantakopoulou 2017, 136-137.

11 Chapter 5.1.2.

12 However, the overall number of honorific texts from the Hellenistic period still surpasses the number of decrees and tituli honorarii from the imperial era. 
granting citizenship. ${ }^{13}$ The trend to naming occupations also follows a Roman epigraphic habit, where occupations were often recorded on tombstones. ${ }^{14}$ This explanation, however, does not allow us to answer the next question that arises with respect to the inclusion of the honorand's profession in Hellenistic decrees. A striking feature of Delphic decrees from the third century BCE is the random manner in which the occupation of the honorand is mentioned. The vast majority of third century proxeny decrees carved upon the walls of the Athenian Treasury do not reveal the profession of those Athenians who were granted Delphic honours, while for instance the decree honouring Timokrates, son of Asklepiodoros, refers to him as a winemaker. ${ }^{15}$ Why was the profession of Timokrates mentioned in this decree and not in other texts? Was it because his deeds toward the city were particularly meritorious? Regrettably, further analysis of the trend does not solve this puzzle. We can only lament that so much escapes our knowledge, since the only testimony we can assess is the preserved epigraphic material.

Before I map the network of honorands, proceeding from the neighbouring areas through the more distance regions to the peripheries, one last general comment needs to be made. The majority of euergetic deeds at Delphi were the result of individual $(84,5 \%)$ rather than communal acts $(15,5 \%) .{ }^{16}$ Collective honorands are most often represented by clusters of foreign ambassadors, embassies and judges, ${ }^{17}$ family members, ${ }^{18}$ hieromnamones,${ }^{19}$ groups of artists, ${ }^{20}$ military commanders ${ }^{21}$ and collective grants for entire poleis. ${ }^{22}$

\footnotetext{
13 Bouchon 2013, 174.

14 Joshel 1977.

$15 \quad F d D$ 2.210.

16145 decrees and four tituli honorarii were granted to collective honorands, whilst 720 decrees and 89 tituli honorarii confer honours upon individuals.

17 E.g. $F d D$ 3.383, FdD 4.225; SGDI 2675; Klio 18.1923.279.207a.

18 E.g. Syll ${ }^{3} 740$ (father and son); $F d D 1.469$ (father and two sons), $F d D 4.387$ (three brothers).

$19 \quad F d D 4.415$.

$20 \quad F d D 2.5$ ( (the guild of Athenian epic poets, see Aneziri 2003, no. A7), $F d D 2.47$ (the guild of theatrical artists from Athens, see Le Guen 2001, no. 10); Syll 682 (a group of painters from Pergamon).

$21 \quad F d D 4.22$ and 4.24 (commanders of Messenian army).

22 Syll ${ }^{3} 292$ (the renewing of collective promanteia for citizens of Naxos); $B C H$ 82.1958.36o (collective promanteia for citizens of Massalia); $F d D 4.155$ (collective promanteia for citizens of Smyrna).
} 


\section{Delphi and Its Interstate Network System: Honorands from Neighbouring and More Distant Zones}

Appendix 3 reveals the chronological distribution of those recipients of Delphic honours whose profession is known and divides them into three zones: honorands from the narrow network (no. 1); those from more distant areas (no. 2); and citizens from the peripheral regions (no. 3). The number of honorands discussed below is small in comparison to the number of all preserved honorary documents from Delphi - and therefore we should be wary of drawing strong conclusions - but some trends are clear nonetheless. First, the narrow network is the most diverse one with respect to the attested categories of honorands (Appendix 3, Table 2). These results highlight the types of links which Delphi had with citizens of Athens as well as Boeotian and Peloponnesian poleis. I have argued in Chapter 3 that Delphi had strong ties with the inhabitants of these regions which continued for more than three centuries. Long-lasting interactions resulted in the creation of more complex links, which were based on various grounds and levels. For example, the citizens of Athens sent to Delphi not only their artists and musicians ${ }^{23}$ (the categories of honorands that dominate in more remote regions), but also public officials representing the state, ${ }^{24}$ priests, ${ }^{25}$ merchants, ${ }^{26}$ and arbitrators. ${ }^{27}$ For citizens from the neighbouring territories Delphi functioned not only as an important religious and artistic hub, but through long-lasting interactions they also connected with Delphi on an economic and political level. This created links that went beyond typical religious or festival connections, and is particularly visible in the procedure of interstate arbitration.

The custom of sending foreign judges has already been discussed in Chapter 2, but a few further points here deserve notice. Analysis of the tabulated data in Appendix 3 reveals that one of the most important factors when choosing an arbitrator was geographical proximity, since the autopsy was often required in the process. ${ }^{28}$ This explains the concentration of foreign judges

\footnotetext{
23 E.g. $F d D 2.105$ (actor), $F d D 4.61$ (grammarian), $F d D 2.5$ o (the guild of Athenian epic poets; Aneziri 2003, A7), $F d D 2.47$ (the guild of Athenian theatrical artists; Le Guen 2001, no. 10).

$26 \quad F d D 2.210$ (if we assume that Timokrates, son of Asklepiodoros, was involved in wine distribution).

$27 F d D$ 2.89. See Tod 1913, no. 22; Nachtergael 1977, no. 34; Ager, 1996, no. 117; Rousset 2002, Inscr. 2.

28 Ager 1996, 13-14.
} 
who originated from Phokian, Boeotian and Peloponnesian cities. ${ }^{29}$ Another relevant factor was the prestige attached to the state or individual. Ager notices that, of the independent Greek states, Rhodes was the favourite choice. ${ }^{30}$ On one occasion in 180/179 or 179/8 вCE the citizens of Delphi used the Rhodian arbitrators in their dispute with Amphissa, which concerned the holy precincts and the borders of some mutually claimed territory. ${ }^{31}$

A further trend which is reflected in the Delphic networks shows the city's interactions with members of the Amphictyony. When approaching this issue, it must be stressed that for centuries the performance of any official functions, whether within the Amphictyonic League or within the organisation of Delphic festivals, represented a 'fast-track' to receiving Delphic gifts. Delphic honorific documents attest many grants for hieromnamones who originate from the neighbouring areas of Aetolia, Phokis, Boeotia and Athens, as well as for the Amphictyonic officials from more remote regions like Chios. ${ }^{32}$ Hermokles, son of Phainomenos from Chios, is worth mentioning in particular, as he was very generous in his donations. He offered a silver crater for the festival of Theoxenia, wrote a hymn for the god, and made a speech during the meeting of the assembly. He was also honoured by the Amphictyony with two crowns - laurel and golden - and with statues. ${ }^{33}$ The largest number of epimeletai and agonothetai came from Aetolia ${ }^{34}$ and Dolopia (Hypata), ${ }^{35}$ while the new political landscape that emerged under Augustus brought epimeletai from Nikopolis. ${ }^{36}$

A similar pattern is discernible in the geographic distribution of theorodokoi. Sanctuaries and poleis that served as hosts of Panhellenic games and other important festivals could not function without the officials responsible

29 Klio 18.1923.279.207a (Lilaia in Phokis); FdD 1.354 (Thebes); SGDI 2662 (Thebes); Klio 18.1923.283.210 (Thespiai); FdD 4.372 (Hermion in Argolis), FdD 3.120 (Magalopolis in Arkadia); Klio 15.1918.33.54 (Sparta).

$30 \quad$ Ager 1996, 11.

$31 \quad F d D$ 3.383. See Ager 1996, no. 117; Rousset 2002, Inscr. 1.

32 A cluster of hieromnamones from different poleis were honoured for their euergetic deeds towards the sanctuary and city $(F d D 4.415)$; the proxeny reward for the Athenian

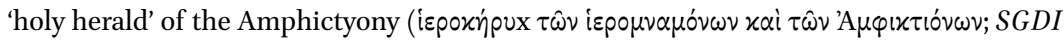
2596); hieromnamones from Tanagra $\left(S y l l^{3} 415\right)$ and Athens $(F d D$ 2.67). For Chian hieromnamones, see $F d D$ 3.224. Lefèvre (2005, 9-34) collected all available evidence concerning hieromnamones from the fifth to first century $\mathrm{BCE}$, paying special attention to these honoured with Delphic proxenia. For the origin, history, competence, and numbers of hieromnamones, see Lefèvre 1998, 205-214 and Sánchez 2001, 498-507.

$33 \quad F d D 3.223$.

$34 \quad F d D$ 1.451.

$35 \quad F d D_{4.63}$.

${ }_{3} 6 \quad F d D$ 4.6o; Syll ${ }^{3} 791 \mathrm{C} ; B C H$ 75.1951.307-8. 
for announcing the organisation of the festival. ${ }^{37}$ Theoroi were sent to all parts of the Hellenic world, and it became customary in every community visited by the theoroi to have a specially appointed person whose duty it was to host and assist the sacred envoys. In return for their help, theorodokoi were granted privileges throughout Greece. ${ }^{38}$ Citizens of Delphi were particularly generous in praising the hosts of their theoroi. At least six decrees confer honours upon the theorodokoi from neighbouring regions, ${ }^{39}$ while two documents attest gifts for theorodokoi originating from Miletos ${ }^{40}$ and Korkyra. ${ }^{41}$ In only one instance were foreign theoroi from a wide network honoured at Delphi, when they came from Knidos sometime during the third century вСE along with other ambassadors to ask for recognition of a festival in favour of Artemis Hyakinthotrophos. ${ }^{42}$

From the preceding discussion it is clear that Delphic relations at a local level reveal more diverse and frequent contacts than those represented by honorands originating from Macedonia, Epirus, the Aegean islands and the west coast of Asia Minor. Apart from the broad categories of artists, 'men of letters' and public officials, ${ }^{43}$ the more distant regions provide only occasional examples such as a physician from Minoa in Amorgos, ${ }^{44}$ athletes and an athletic trainer from Smyrna. ${ }^{45}$

All types of artists, musicians and 'men of letters' are among the most numerous categories attested in all three regions. This trend should not be surprising but should instead be associated with the character of Delphi. With its centuries of festivals and Pythian Games, Delphi served, along with Athens, as a Panhellenic stage where artists from all over the Mediterranean could demonstrate their skills to a wide audience. ${ }^{46}$ After two centuries of decline,

37 Perlman 1995 and 2000; for brief definition, see Hansen and Nielsen 2004, 103.

38 For religious, festival and athletic networks, see Collar 2013; van Nijf and Williamson 2016, 43-73; Mann 2018 293-312; Rutherford 2019, 165-181; Papazarkadas 2019, 205-221; Steinhauer 2019, 223-237.

FdD 2.55 (theorodokos from Athens); BCH Suppl. 4.136,ng and BCH 83.1959.484,16 (theorodokoi from Antikyra in Phokis); FdD 4.173 (theorodokos from Lepreon in Arkadia); Syll ${ }^{3}$ 189 (theorodokos from Stymphalos in Arkadia); FdD $1.15^{2}$ (theorodokos from Naupaktos in west Lokris).

$40 \quad F d D 2.88$.

$41 \quad F d D$ 4.406.

$42 \quad F d D 1.308$.

43 Ambassadors, theorodokoi, hieromnamones, epimeletai and agonothetai.

$44 \quad F d D$ 3.298; Samama 2003, no. 65.

45 Syll 740 and $F d D$ 1.220. Choix 2012, no. 193.

46 The literature on artists attested at Delphi is plentiful: for instance Bouchon (2013, 171-193) examines the musicians honoured at Delphi and types of privileges granted upon them; Perrot $\left(2013,195^{-210}\right)$ focuses on the female musicians praised at Delphi; Bouvier (1985, 
Delphi flourished again during the times of Plutarch, Herodes Atticus and Hadrian. ${ }^{47}$ The largest number of honorific decrees bestowed on Athenian artists and 'men of letters' was granted in the first half of the second century CE. ${ }^{48}$ In this time-period the citizens of Delphi honoured many philosophers ${ }^{49}$ and rhetors; ${ }^{50}$ the bulk of these belong to the Delphic wide network of honorands.

Interactions that lasted throughout the centuries resulted in the creation of multilayer links. Regrettably, the Delphic network of honorands does not allow for interaction concerning economics or trade to be investigated in great detail..$^{51}$ However, the geographic distribution of honours does showcase relationships that the citizens of Delphi chose to highlight throughout the centuries and immortalise by inscribing the texts of honorific inscriptions within the temenos.

\subsection{Delphi and Its Wide Network System}

Interactions of Delphic polis with honorands from the peripheral zone has already been briefly discussed. This section will focus on the city's relations with the 'elite of an elite', i.e. with the people who held positions in one of the Hellenistic monarchies or the Roman imperial household, or who were closely affiliated to royals and/or belonged to a ruling family. ${ }^{52} \mathrm{I}$ will approach my data using two different levels of analysis. Firstly, I will explore Delphic links with the Hellenistic kings in comparison with other Greek main sanctuaries (that is, with Delos, Didyma and Olympia). Secondly, I will zoom in on Delphic connections with Rome and Roman emperors.

\subsubsection{Delphi and the Hellenistic Kings}

Analysis of the preserved honorific documents from Delphi makes it clear that Delphi did not attract the attention of the major figures of the Hellenistic world apart from the ruling kings of Pergamon. Table 6 in Appendix 3 reveals

119-135) discusses 'men of letters' granted with honours at Delphi; and van Liefferinge (2000, 149-164) examines poets, musicians, actors, philosophers, teachers (grammarians) and astronomers that are recorded in Delphic documents. See Chapter 5.1.2.

47 Bourguet 1914, 205-206; Agusta-Boularot 1994, 734-735.

48 Bouvier 1985, 119-135.

$49 \quad F d D 1.199$ (Antiochia), $F d D 1.203$ (Smyrna), $F d D 2.116$ (Thmouis in Egypt), $F d D 4.91$ (Berytos), FdD 4.94 (Mallos in Kilikia), FdD 4.115 (Nikopolis).

50 $\quad B C H$ 63.1939.168,696 (Rome); $F d D 1.204$ (Antiochia), FdD 2.109 (Gaza).

$5^{1} \quad$ For the economic network, see Archibald 2001, 245-272.

$5^{2}$ I use the term 'elite of an elite' after Constantakopoulou 2017, 218. 
only nine honorific decrees and one titulus honorarius that attest honours granted by the city of Delphi to Hellenistic monarchs (or their philoi). The earliest attestation is a mid-fourth century BCE proxeny decree dedicated to four sons of Kersebleptes, a Thracian king who was certainly not one of the main Hellenistic kings. ${ }^{53}$ The decree, however, reveals an interesting trend in Delphic honorific culture, namely the city's links with peripheral regions and their sovereigns. It can be also interpreted as part of the process of Hellenisation in the region. The four sons of Kersebleptes bore Greek names (Iolaos, Poseidonios, Medistas and Teres), while the granting of Delphic proxenia enrolled them into the Greek world of honours. Kersebleptes' family thus not only established connections with Delphi but also facilitated their integration with Greeks by becoming a close ally of Athens. ${ }^{54}$ In 357 BCE a final treaty was negotiated between Athens and three sons of Kotys, dividing the Thracian kingdom into three parts; Berisades took the western part, Amadokos the central part, and Kersebleptes the eastern part. ${ }^{55}$ Shortly after this, Kotys' sons joined Athens and others in an alliance against Philip II. ${ }^{56}$ Again in 276/5 BCE another ruler of Thrace, the Odrysian king Kotys III, son of Raizdos, was proclaimed a Delphic proxenos. ${ }^{57}$

Another example of honours being conferred upon the rulers of peripheral kingdoms is a decree dedicated to Pairisades IV, king of Bosporus and his mother, queen Kamasarye, daughter of king Spartokos VI. ${ }^{58}$ Unfortunately, only the upper part of the decree has survived and the reason for the granting of privileges is lost. Bringmann and von Steuben's catalogue of royal donations, which attests further donations of the Bosporan kings at Athens, Delos and Didyma (all the main Greek sanctuaries) suggest that it is a Delphic answer to some offering. ${ }^{59}$ Although no honorific decree for Dropion, king of Paeonia, is preserved (or is known ever to have been granted), two votive offerings reveal his donations at Delphi and thus his interest in becoming integrated into the Greek world. ${ }^{60}$ The honorific decree for king Nikomedes III of Bithynia and queen Laodike, daughter of Mithridates v, also offers a snapshot of Delphic relations with Bithynia. ${ }^{61}$ This decree was engraved upon the grand

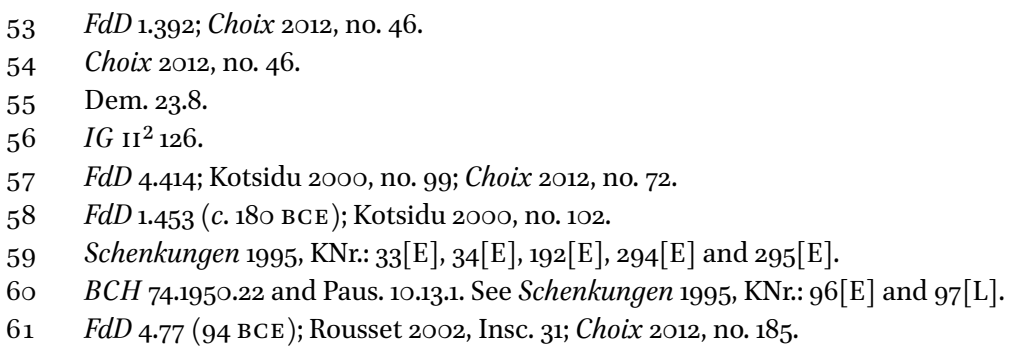


pillar dedicated by the Aetolians to Prusias II, another Bithynian king. ${ }^{62}$ The royal couple sent thirty slaves who were later assigned to various activities at the sanctuary.

Hannestad suggests that, through their benefactions to Greek sanctuaries, these marginal kingdoms revealed their strong philhellenic attitudes. ${ }^{63}$ Apart from Delphi, the Bithynian rulers made donations at Delos, Rhodes, Didyma and perhaps Kos, following the same pattern as the Bosporan kings of imprinting their presence in the most important religious and political centres in Greece. ${ }^{64}$ We are therefore entitled to expand on Hannestad's theory and to conclude that Greek honorific culture enabled mutual relations; through their euergetism the rulers of peripheral kingdoms expressed not only their philhellenism, but also, as argued in Chapter 3, their 'need to belong' to the Greek world. In return, Greek poleis granted them honorific titles and gifts on a par with other citizens of the Mediterranean in order to facilitate their integration. ${ }^{65}$

At some point during the Hellenistic period the citizens of Delphi established relations with the rulers of Pergamon. The proxeny grant for Philetairos, his (adoptive) son Attalos and his brother Eumenes, the father of the future king Eumenes I, resulted in a series of documents that attest Delphi's close links with the Attalids. ${ }^{66}$ Burstein has argued that Philetairos and his relatives obtained Delphic privileges for some offerings for the sanctuary, as similar donations are attested on Delos and in Thespiai. ${ }^{67}$ Apart from Philetairos, two other Attalid kings were praised by Delphic citizens. Firstly, Eumenes II received honours for his generous donations, which included money for the grain supply and money for workers required for the reconstruction of the theatre. ${ }^{68}$ Secondly, the statue of Attalos II was probably a Delphic thanksgiving for his donation made for the education of children and the organisation of a festival called Attaleia. ${ }^{69}$ Also, the Amphictyony and the Aetolians expressed their gratitude to Eumenes II for his benefactions at Delphi by granting him statues and a crown. ${ }^{70}$

$62 \quad F d D 4.76$.

63 Hannestad 1996, 67-98.

64 Schenkungen 1995, KNr: 98 [E], 188[E], 189[E], 217[L], 288[E], 289[E], 29o[E], 424[A].

65 Chapter 3.1.

$66 \quad F d D 1.432$ (282-262 BCE); Kotsidu 200o, no. 9o; Choix 2012, no. 65.

67 Burstein 1985 , no. 84 .

$68 F d D$ 3.237. For Attalids relations with Delphi, see Choix 2012, nos. 118, 127, 140, 155, 163-164 and $171-172$.

$69 \quad F d D$ 3.121. Choix 2012, no. 168.

70 Amphictyonic decree ( $F d D$ 2.361; Choix 2012, no. 155); Aetolian honorific inscription (FdD 3.230; Choix 2012, no. 140). 
One of the most striking features of the Delphic honorific habit is the lack of preserved honours for members of the Seleukid and Ptolemaic dynasties. ${ }^{71}$ The available evidence reveals only one honorific decree attesting the commendation of Seleukos II. ${ }^{72}$ No other sources, either literary or epigraphic, bear witness to honours granted to another Seleukid at Delphi. It is open to question whether Dikaiarchos, son of Philonides from Laodikeia (who hosted Delphic theoroi sent to Antiochos III), was a member of the Seleukid royal court, since a similar decree was granted in $157 / 6 \mathrm{BCE}$ by the citizens of Delphi for the close ally of Ptolemy VI. ${ }^{73}$ Seleukos, son of Bithys from Alexandria, also accompanied Delphic theoroi sent to the Ptolemaic king. ${ }^{74}$ In contrast to Dikaiarchos, Seleukos was a well-known person, inasmuch as he was granted privileges on Cyprus, in Olympia and on Crete. He also performed the duty of chief-priest and king's advisor in Alexandria, where he held the distinguished court title of syngenes. ${ }^{75}$

If we contrast Delphi with other sanctuaries and cities, we may obtain an interesting view of the role that particular poleis played in the processes of connecting with the new territorial powers. The case of Athens reveals a rich array of honours conferred upon members of all the main Hellenistic dynasties, including the Seleukids, Ptolemies, Antigonids and Attalids. ${ }^{76}$ This should not surprise us, since Athens always played a central role in Greece and its historical events. Pausanias explains the reasons behind the Athenian decision to erect statues of Ptolemy III, Antigonos I Monophthalmos and his son Demetrios at Delphi as follows: '[ $t$ ]he statue of the Egyptian they sent out of good-will; those of the Macedonians were sent because of the dread that they inspired. ${ }^{77}$ Due to their strategic location in the Aegean basin, Delos and Rhodes held privileged positions within the Ptolemaic sphere of influence and Ptolemaic foreign politics - which explains the large number of both donations and gifts for the Ptolemies. The Seleukids were naturally favoured in

71 According to Pausanias' testimony, Athenians sent Delphi statues of Ptolemy III, Antigonos I Monophthalmos, and his son, Demetrios (Paus. 10.10.2. Kotsidu 2000, nos. 86[L] and 87[L]). Epigraphic evidence reveals honours bestowed upon Antigonos III by the League of the Amphictyony (FdD 4.163; Kotsidu 200o, no. 89[E]).

$72 \quad F d D$ 4.153; Rigsby 1996, no. 7; Kotsidu 200o, no. 88; Choix 2012, no. 81.

73 SGDI 2677; Nachtergael 1977, no. 36 .

$74 \quad F d D 4.161$.

75 Choix 2012, no. 169 with further bibliography; OGIS nos. 150-162.

76 Kotsidu 200o, nos. $1-49$.

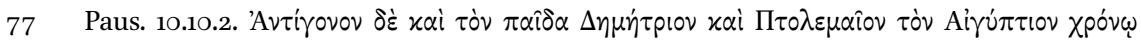

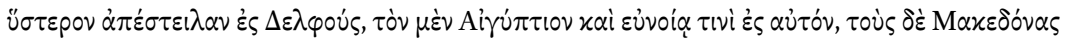

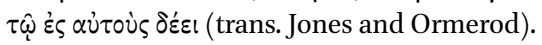


Didyma. ${ }^{78}$ Delphi's and Olympia's relations with the Ptolemies and Seleukids were similarly poor. ${ }^{79}$ So did other poleis in central Greece. ${ }^{80}$

The limited number of sources attesting Delphi's interactions with the Ptolemies, Seleukids and the Antigonid dynasty suggests two things: first, that Delphi (and in fact the whole of central Greece) did not hold a privileged position within the new monarchies; and second, since the privileges were a response to euergetism (or a stimulation for it), that the evidence for royal benefactions at Delphi is also rather poor.

Unpacking the available evidence of royal donations at Delphi and beyond using Bringmann and von Steuben's collection allows us to present the material in the form of the following graph in Figure 11:

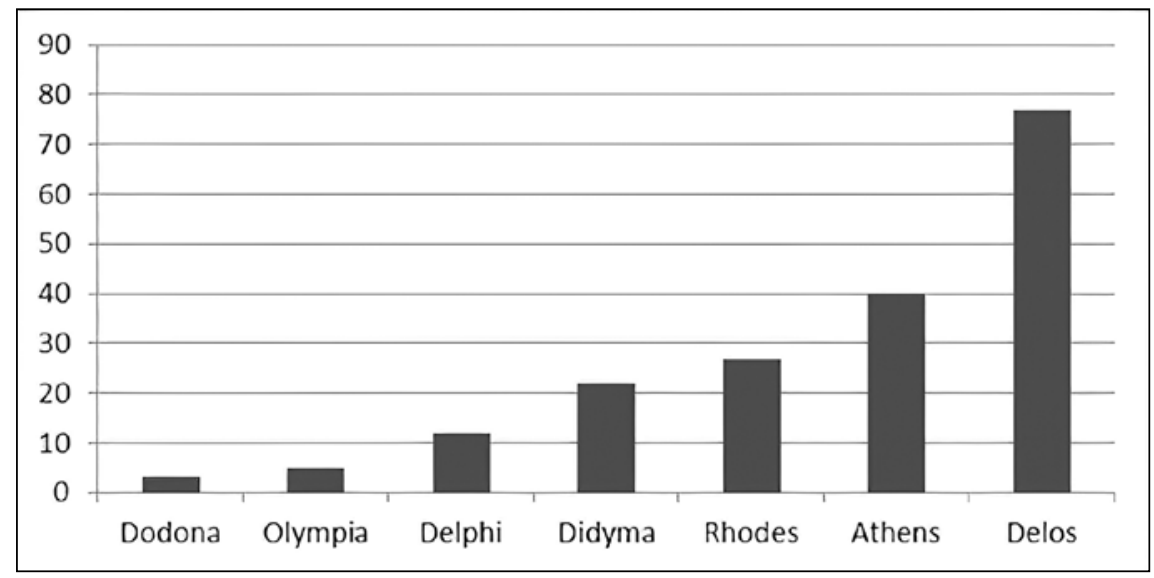

FIGURE 11 The number of royal donations

Note: After Schenkungen 1995. See also Lala 2016, 91-99.

This graph mirrors the trends discussed so far. Athens, Rhodes, Didyma and Delos in particular, due to their strategic political locations, managed to establish solid and mutual links with the Hellenistic kings and their courts. In the Hellenistic era the citizens of Delphi created a wide network of honorands originating from all over the Mediterranean, including the peripheral regions of Epirus, Thrace and the Bosporan kingdom; yet, weak links with the main

78 Paus. 1.16.3, Kotsidu 200o, nos. 262-282.

79 Kotsidu 200o, nos. 64-76.

8o Kotsidu (2000, nos. 82-106) collected 24 attestations of honours conferred upon the Hellenistic monarchs and their families in central Greece: 20 evidence come from Delphi, two from Thermon, one from Oropos and one from Kallion. 
Hellenistic monarch demonstrate Delphi's marginal political role. The word 'political' is crucial in this context, since Delphi's wide proxeny networks during the third and second centuries prove that the city remained a main religious and social hub of Greece that linked not only Greeks but also inhabitants from peripheral territories with the centre.

\subsubsection{Delphi and the Advent of Rome}

Apart from Magna Graecia, the territory of central Greece was the first place where Rome interacted with the Greeks. The earliest example of honorific distinction awarded by the polis to individual Romans, which dates to as early as the third century BCE, is the list of proxenoi from Thermon. ${ }^{81}$ According to Livy, Romans consulted Delphic oracle already in the sixth century вС ${ }^{82}$ The senatorial dedication of the golden bowl at the sanctuary of Apollo after the Roman victory at Clastidium in $222 \mathrm{BCE}$ is, however, the first historically certain Roman contact with Delphi. ${ }^{83}$ The citizens of Delphi took advantage of this dedication and in the succeeding years led to the development of mutual relations between the two cities. Delphians perceived the Romans as the potential saviours who would liberate the sanctuary from the Aetolian supremacy that had oppressed Delphi for over 50 years. The Roman generals of the first half of the second century вСе (M'. Acilius Glabrio, ${ }^{84}$ T. Quinctius Flamininus, ${ }^{85}$ L. Aemilius Paullus ${ }^{86}$ ) were commemorated there not only as liberators, but also as protectors of Delphi's sacred territory. ${ }^{87}$ Over time, other cities followed Delphi's pattern and started to grant honorific statues to Roman magistrates and military commanders. ${ }^{88}$ This spread of portraits of Roman officials suggests the spread of Roman supremacy to a larger horizon. ${ }^{89}$

Delphi's interactions with Rome and Roman emperors have already been discussed in other chapters; here I want to focus on the categories of Romans

$81 I G$ IX, $1^{2}$ 17. The list dates to $263 / 2$ BCE (Habicht 1982, 382-383) or to 271/о вCE (Grainger 200o, 65). See Zoumbaki 2017, 246.

$82 \quad$ Liv. 1.56.

83 Plu. Marc. 8.6. Eckstein 2008, 42.

84 Praised by the Delphic city (Syll $\left.{ }^{3} 607\right)$ and the Amphictyony (CID 4.103). See Choix 2012, nos. 143-144.

85 Syll 616 ; Choix 2012, no. 151.

$86 \quad F d D$ 4.36; Choix 2012, no. 161.

87 Galli 2013, 23-27.

88 For instance in Olympia, Delos, and Pergamon. See Zoumbaki 2010, 112; Griesbach 2013, 83-125; Mathys 2014a, 43-56; Mathys 2014b.

89 Payne 1984, 48 and table 2 on pp. 42-43. For the chronology and typology of Roman portraits in Greece, see Schröder 2011. 
attested among the recipients of Delphic gifts. ${ }^{90}$ Such an analysis allows us to answer the questions posed in the introduction to this chapter: how did the categories of honorands evolve over time?; what was the status of the persons granted honours?; and how did the citizens of Rome earn Delphic privileges?

Roughly $45 \%$ of the recipients of Delphic gifts who came from Rome and Italy were men who served in Greece as army commanders or magistrates. This percentage is not surprising, in view of the extent of Roman military involvement in Greece during the period under consideration. Five Romans held high commands as consul or proconsul. ${ }^{91}$ Among the lower-ranking recipients (thirteen men), we find a procurator of Pannonia and Achaia, ${ }^{92}$ two quaestors (one propraetorian), ${ }^{93}$ a propraetorian legatus ${ }^{94}$ and an evocatus. ${ }^{95}$ A decree dedicated to Asinius Rufus also illustrates his career starting, from the highest office he performed (praetor), through the less prominent (procurator), to the lowest ones (tribunus cohortis, praefectus cohortis). ${ }^{96}$

Usually honours were issued either while in office or not long after the term ended. By commissioning privileges for a current office-holder, the city may have hoped for further reciprocal benefactions while the man was still in office. ${ }^{97}$ Whilst it is open to question whether Roman magistrates had any real interest in making use of their privileges in Greek poleis, for private Romans who were already residents of the city in question, the award of various distinctions and special rights was certainly an important matter..$^{98}$ It is striking that $40 \%$ of all instances of Romans who were granted proxeny in

90 See Chapter 1. Daux 1936, 225-233 and 584-6o5; Sánchez 20o1, 364-465; Grzesik 2019, 210-219.

91 1) Klio 17.1921.162.147 (151 BCE): one of four known Delphi's patrons, A. Postumius Albinus, was a consul of 151 BCE (see Eilers 2002, App.1 C15); 2) FdD 1.526 (c. 100 BCE): M. Minucius Rufus, also a Roman consul (see Choix 2012, nos. 178-181); 3) FdD 1.532: P. Memmios Regulus, honoured along with his son (44-63 CE), was a consul and proconsul of Asia; 4) FdD 4.47 (98 CE): C. Caristanius Iulianus, a proconsul of Achaia (see Choix 2012, no. 242); and 5) FdD 4.269 (175-225 CE): Cn. Claudius Leonticus, a proconsul of Achaia (see Choix 2012, no. 267). One late fragmentary honorific inscription might also have been granted to an unknown Roman consul (CID 4.169). Corsten (1997, 117-122) examines the literary and epigraphic sources on Greek proconsulae.

$92 \quad F d D 4.473$ (212 CE), C. Publicius Proculeianus, see Pflaum 196o, no. 285.

$93 F d D 1.528$ (c. 14 BCE), C. Lentulus, son of Gaius, grandson of Gaius, see Cébeillac 1972, no. 1; Schörner 2003, 1032 and $F d D 4.247$ (second century BCE).

$94 \quad F d D 1.318(49 / 8$ в $\mathrm{CE})$.

$95 \quad F d D 1.205$ (second or early third $\mathrm{CE}$ ).

$96 \quad F d D 4.48(101-125 \mathrm{CE})$.

97 Payne 1984, 28.

98 Zoumbaki 2017, 249-25o. 
mainland Greece and the Aegean islands (third-first century ВСЕ) came from Delphi. ${ }^{99}$ Apart from proxenia and other accompanying privileges, Romans were honoured at Delphi with enktesis, ${ }^{100}$ citizenship and bouleuteia, ${ }^{101}$ and honorific portraits. 102

For now it is worth pointing out that Delphi had links with Rome almost exclusively through the public sector. ${ }^{103}$ Apart from high-ranking Roman magistrates and military officials the citizens of Delphi praised only artists from Puteoli ${ }^{104}$ and Rhegion ${ }^{105}$ and one Roman astrologer. ${ }^{106}$ Delos had more extended connections with Romans through the private sector than the rest of Greece. This was principally due to commerce, inasmuch as many of the Roman recipients of Delian gifts were involved in some form of trade, while no such links are attested at Delphi. ${ }^{107}$

I now turn to addressing the next category of Romans honoured at Delphi Roman emperors. Table 4 reveals a list of Roman emperors and their relatives praised with honorific portraits by the Delphic city.

In order to obtain a full picture of Delphi's contacts with the Roman emperors during the imperial period, one should also include statues voted by the League of the Amphictyony as well as by Delphic private individuals (Appendix 4). This approach reveals that almost all emperors of the Julio-Claudian dynasty were honoured at Delphi. ${ }^{108}$ The new rulers of the empire gained Greek favour by votive offerings sent to the main Greek

99 Zoumbaki 2017, Appendix 2. See also Marek 1984, 382-384.

100 Zoumbaki $(2017,265)$ lists three instances.

$101 F d D 1.205$ (second century CE or early third century CE), FdD 4.48 (101-125 CE). C. Iulius Pudens, who served as frumentarius, was honoured with a Delphic citizenship by the damiourgoi during Hadrian's reign, see Choix 2012, no. 25o. For Delphic damiourgoi, see Vatin 1961, 236-255; Vatin 1970, 259-263; Ferrary and Rousset 1998, 297-299; Hamon 2009, 373-378; Grzesik 2018b, 117-139. For damiourgoi in other Greek poleis, see Veligianni-Terzi 1977, 51-55 and 90-96; Zoumbaki 2001, 90-95.

102 E.g. Syll ${ }^{3} 710 \mathrm{C}$ (10о вСE), Syll ${ }^{3} 774 \mathrm{~A}$ (first century вСE); FdD 1.532 (44-63 CE).

$103 F d D 4.269$ constitutes a rare example of an honour granted by a private individual (Aurelius Marcus, sic!) to a Roman, one Cn. Claudius Leonticus, who received a statue in Delphi. See Rousset 2002, 144-145 and 280-281; Choix 2012, no. 267.

$104 F d D$ 4.34. See Guarducci 1969, vol. II, 56-57; Choix 2012, no. 287.

$105 B C H 73 \cdot 1949 \cdot 276,27$.

106 Syll ${ }^{3} 771$; Choix 2012, no. 281.

107 Payne 1984, 33; Zoumbaki 2017, 247-249.

108 Tiberius ( $F d D$ 1.530); Caligula (IG VII 2711); Caligula or Claudius (Klio 17.1921.166-7); Claudius ( $F d D$ 1.531); Nero ( $F d D$ 4.258); Agrippina (Syll ${ }^{3} 809$ ); M. Agrippa's children ( $F d D$ 4.256 A and B plus $S y l l^{3} 779 \mathrm{C}$ and D). Moreover, the herm of Augustus was dedicated at Delphi by the Athenians $(B C H$ 85.1961.88) and a statue of Caligula by the citizens of Achaia, Boeotia, Phokis and Euboia (IG VII 2711). See Grzesik 2019, 212. 
TABLE 4 Roman emperors honoured by the Delphic $p o l i s^{\mathrm{a}}$

\begin{tabular}{ll}
\hline $\begin{array}{l}\text { Emperors } \\
\text { (along with their relatives) }\end{array}$ & No. of statues \\
\hline Tiberius & 1 \\
Claudius & $1+1$ possible (Caligula?) \\
Nero & (Agrippina the Younger) \\
Titus & 1 \\
Nerva & 1 \\
Hadrian & 2 \\
Severus & 1 \\
Alexander & 1 \\
Gordian III & 1 \\
Valerian & 1 \\
Gallienus & 1 \\
Carus & 1 \\
Constantius I & $1+1$ (him or Dalmatius) \\
Constantine the Great & 1 \\
Constans I & 1 \\
Valentinian I & 1 \\
Valens & \\
\hline
\end{tabular}

a The list includes only these emperors (or their relatives) who were praised by the city of Delphi.

sanctuaries. In the early Julio-Claudian period, Delphi and Delos were showered with Roman dedications. ${ }^{109}$ In return, Delphi honored emperors with statues, which should be seen as public and permanent expressions of local honour, while a commemorative inscription accompanying a statue became a symbol of a long-standing tradition of reciprocity.110

In contrast to the emperors from the Julio-Claudian dynasty, the members of the Flavian family were granted with only one honorific portrait at Delphi. Vespasian was not a popular emperor among the Greeks, to judge from the fact that there are only nine attestations of his statues in Greece. ${ }^{111}$ Striking, however, is the lack of images of Domitian, Delphi's great benefactor and

109 Galli 2013, 37; Griesbach 2013, 83-125.

110 Noreña 2021, 205.

111 Højte 2005, 15 o. 
administrator. ${ }^{12}$ Perhaps the citizens of Delphi honoured Domitian with a statue, as they did his brother Titus and his successor Nerva, although the image and the inscription did not survive due to Domitian's official damnatio memoriae. ${ }^{113}$ It seems that the citizens of Delphi did not want to recognise new dynasties too quickly. When the new imperial family's position became more secure and it was widely known that Titus would succeed Vespasian, the Delpians more willingly founded his statues.

After two centuries of decline, during the second century CE Delphi flourished again. ${ }^{114}$ In return for their philhellenism and interest in Delphi, Nerva, Trajan and Hadrian received seven honorific statues at Delphi, whilst the citizens of Delphi set up a family monument of the Antonine family in Rome. ${ }^{115}$

I have argued elsewhere that the time of the Severan dynasty was a crucial period for Delphic statuary production, as well as for the entire epigraphic habit. ${ }^{116}$ From the reign of Severus Alexander (who was the only emperor praised at Delphi from the Severan dynasty) the honorific culture began a slow slide into decline. From the mid-third century CE the Roman emperors remained the only recipients of Delphic honours. ${ }^{117}$ In times of constant insecurity concerning who would rule the empire, the Delphic authorities did not raise portraits of emperors whose reigns lasted less than five years. An exception to this rule is an image of Carus, who reigned for less than a year; his statue was reused almost immediately after his death for the monument of Constantinus Chlorus. ${ }^{118}$ Images of Valens and Valentinian I from 365 CE were the last honorific monuments set up within the temenos at Delphi. ${ }^{119}$

\subsection{The Female Honorands}

The last section of this chapter is devoted to women praised at Delphi to reveal the gender dynamics of the honorands. Table 5 shows that the change in proportion of benefactresses was both quantitative and qualitative over time,

\footnotetext{
112 Weir (2004, 98 and 146-158) argues that the uncertain, so-called Emperor's monument, represents Domitian, but it might also have been a representation of Augustus.

113 For the overall number of statues granted at Delphi during the reign of the Flavian dynasty, see Grzesik 2019, 213-214.

114 See Chapter 1. Weir 2004, 172.

115 Nerva ( $B C H$ 76.1952.627,2); Trajan (CID 4.149 and Syll $\left.{ }^{3} 825 \mathrm{~B}\right)$; Hadrian (Syll ${ }^{3} 829 \mathrm{~B}$, Syll ${ }^{3}$ $835 \mathrm{~A}$ and B; $F d D$ 4.472); Antonine portrait in Rome ( $I G$ XIV 1050=IGUR I 25).

116 Grzesik 2019, 216.

117 Jacquemin 1999, no. 153; Choix 2012, no. 270; Grzesik 2019, 217-218.

118 Syll 897; Jacquemin 1999, no. 153; Choix 2012, no. 270.

$119 \quad$ BCH 86.1962.238.
} 
TABLE 5 The number of women honoured at Delphi

Date No. of female honorands

$\begin{array}{ll}\text { 4th century ВСЕ } & \text { O } \\ \text { 3rd century ВСЕ } & 1 \\ \text { 2nd century BCE } & 5 \\ \text { 1st century BCE } & 3 \\ \text { 1st century CE } & 5 \\ \text { 2nd century CE } & 6 \\ & +3 \text { texts dated to the } \\ & 2 \text { nd /3rd century CE } \\ \text { 3rd century CE } & 1 \\ \text { Undated } & 1\end{array}$

since there was a significant peak in the number of honours bestowed upon women in the imperial period compared to the Hellenistic era.

Tituli honorarii provide eighteen instances of Delphi's benefactresses, while seven attestations are found in honorific decrees (the presence of male relatives in four decrees suggests, however, that these women were honored because of their relationship to these men). Therefore, the ratio of women praised with statues is higher than the ratio of those who were granted decrees. The bulk of statues voted for Delphi's benefactresses were dedicated during the imperial period; this marks a significant change in the Delphic honorific culture and the introduction of a new trend. Regarding the political context of such honours, the fact that the honours were carved in stone and set up in conspicuous places at Delphi reflects what the male part of the city populace thought about women in general and their presence in public space in particular. Gauthier explains the relatively late appearance of women as recipients of public gifts by the fact that, until the late third-early second century BCE, the gift-giving system was tied to performing civic offices (which women could not hold), whereas from the mid-second century onwards the nature of euergetism changed and with it the criteria for being a benefactor. ${ }^{120}$ The case of Delphi thus follows a common Greek pattern.

It is believed that, since women did not travel as often and as far as men, they tended to become benefactresses within their own poleis or in the neighbouring

120 Gauthier 1985, 74-75. 
areas rather than in more remote areas. ${ }^{121}$ On Delos, for instance, the female dedicants came from the closest geographical islands, namely Mykonos and Naxos. ${ }^{122}$ A similar tendency is mirrored in the ratio of local women to foreign benefactresses praised at Delphi. Fourteen out of 25 women honoured with Delphic gifts were local benefactresses belonging to the top echelons of society. Many of them, such as Pasichon, wife of Xenon, ${ }^{123}$ or Memmia Lupa, daughter of P. Memmios Soteros, ${ }^{124}$ performed as priestesses. Only four out of fourteen honours were public acts; the remaining ten were private dedications.

Only two of the foreign benefactresses came from places in the narrow network (Athens and Thebes), ${ }^{125}$ two came from more distant regions (Kyme in Aeolis and Nikopolis), ${ }^{126}$ and seven from distant areas (Rome, Bithynia, Bosporus and Tralles Caesarea). ${ }^{127}$

A large proportion of foreign benefactresses were wives, mothers or members of the royal court. These include queen Kamasarye, the mother of the Bosporan king Pairisades IV, ${ }^{128}$ queen Laodike, the wife of Nikomedes III of Bithynia, ${ }^{129}$ and the wife of Asinius Rufus, who was honoured along with her husband and sons. ${ }^{130}$ Several women were praised on their own, such as Appia Regilla, wife of Herodes Atticus. ${ }^{131}$ Her acts of euergetism toward Delphi should rather be treated as a part of Herodes Atticus' benefactions, as the honorific inscription voted for her is a part of a larger group of honours bestowed by the Delphians on the Herodes family. ${ }^{132}$ In three instances, however, the woman's own actions were rewarded. All these decrees postdate 15 о BCE. The earliest attestation concerns a harpist from Kyme in Aeolis who received a crown, bronze statue, monetary reward and other standard privileges for her performance at Delphi. ${ }^{133}$ Almost 50 years later another harpist was granted proxenia, promanteia (priority to consult an oracle), proedria (privilege of

\footnotetext{
121 van Bremen 1996.

122 Constantakopoulou 2017, 214.

123 FdD 4.242. See Daux 1936, 453; Choix 2012, no. 142.

124 Bourguet 1905, 13; Puech 1992, 4849-485o; Jacquemin 1999, no. 258 and p. 45; Choix 2012, no. 226 .

$125 F d D_{3 \cdot 71,} F d D_{3.249}$.

$126 S y l l^{3} 689$ and Bourguet 1905, 30.

127 Rome - FdD 4.48; Syll ${ }^{3}$ 8o9; $B C H$ 70.1946.254,8. Bithynia - FdD 4.77 and $F d D$ 4.79. Bosporus - FdD 1.453. Tralles Caesarea $-F d D$ 1.533.

$128 F d D 1.453$.

129 FdD 4.77 (94 BCE); Rousset 2002, Insc. 31; Choix 2012, no. 185.

$130 \quad F d D 4.48$.

$131 \mathrm{FdD} 3 \cdot 71$.

132 Cf. Choix 2012, nos. 256-264; Ameling 1983, nos. 103-110 and 176.

133 Syll 689 (134 BCE). See Bouchon 2013, 171-193.
} 
front-row seats), prodikia (priority of trial), asylia (immunity from the right of reprisal), ateleia (exemption from public burdens), and other minor privileges at Delphi. ${ }^{134}$ Finally, Auphria, a public speaker from Bithynia (?), is known from a second century CE fragmentary decree that confers upon her Delphic

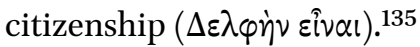

In conclusion, it seems that Delphi followed the same pattern as the rest of mainland Greece with regard to conferring honours upon women. The number of local women surpasses the number of foreign benefactresses, and their predominance is visible throughout the imperial period, in the second century CE in particular. Almost $24 \%$ of all honorific images erected at that time represent women. This figure is of course low in relation to the actual number of women in the community, yet it is high in relation to the norms of ancient statue practice. ${ }^{136}$ The portion of female statues throughout the entire Hellenistic and Roman periods was $16 \%$, whereas during the Antonine period it rose to $8 \%$ higher $(24 \%)$ - another sign of the ongoing oligarchisation of the city.

\subsection{Conclusion}

Examining 700 years of Delphic honorific documents is sufficient to demonstrate that honorific practice at Delphi did not stand still and that the recipients of gifts changed and evolved over time. Whereas in the early Hellenistic period the honorific habit was represented by foreign, mostly male benefactors, from the second century ВСЕ onwards members of the local elite and women entered into the group of benefactors. The first examples of local individuals are not attested until $c .189$ BCE. ${ }^{137}$ Foreign benefactresses make their first appearance more or less in the same period. ${ }^{138}$

134 FdD 3.249. See Bélis 1999, 53-55; Chaniotis 2009, 87-91; Choix 2012, nos. 208-209; Perrot 2013, 205-206. See also Chapter 6.1.2.

$135 F d D$ 4.79. Auphria's origin is not known, but the rare ending of her ethnicon (-vos) may suggest that she came from Bithynia, since the decree was engraved upon the pillar of Prusias II, Bithynian king, see Puech 2002, 53.

136 van Bremen 1996; Smith 2006, 5-7.

137 The statue of Aristoklea, set up by her parents, is dated by the editors to the early third century вСЕ ( $F d D$ 4.259). More probably it comes from no earlier than the late third century $\mathrm{BCE}$, to judge from the absence of any surviving private statues from this century at Delphi, whereas they appear abundantly in the sample from the following century.

138 Queen Kamasarye was honoured along with her son $c .18$ о-150 вСЕ ( $F d D$ 1.453). Polygnota from Thebes was the first women praised alone $(F d D$ 3.249, 86 ВСЕ). 
Relations at a local level (the narrow network) allowed for the creation of deeper, more long-lasting interactions, based on more complex and diverse grounds than those links created by honorands originating from the more remote areas. Since epigraphic and literary evidence naturally favours the aristocracy, most of the preserved honorific documents from Delphi concern the top echelons of ancient society. Delphic documents, however, also reveal honours granted to those from lower social classes. Two decrees confer honours upon synoikoi, i.e. permanent residents of the city without citizenship, who might have been manumitted slaves. 139

139 SGDI 2606 and 2607; Choix 2012, nos. 112 and 113. Perhaps Philistion and Teisimachos, two physicians, were also synoikoi (Syll 437 and Syll 481 B; Choix 2012, no. 111). For the status of synoikoi in Greece, see Strubbe 2001, 29. 